\title{
SOME PROPERTIES AND INEQUALITIES FOR $h$-GEOMETRICALLY CONVEX FUNCTIONS
}

\author{
Bo ZHANG, Bo-YAN XI AND FENG QI
}

\begin{abstract}
In the paper, the definition of $h$-geometrically convex functions is introduced, some properties of $h$-geometrically convex functions are studied, and several integral inequality for the newly defined functions are established.
\end{abstract}

Mathematics subject classification (2010): Primary 26A51; Secondary 26D15, 41A55. Keywords and phrases: property, $h$-geometrically convex function, inequality.

\section{REFERENCES}

[1] R.-F. BAI, F. QI, AND B.-Y. XI, Hermite-Hadamard type inequalities for the $m$ - and $(\alpha, m)$ logarithmically convex functions, Filomat 27 (2013), no. 1, 1-7, available online at http://dx.doi.org/10.2298/FIL1301001B.

[2] S.-P. BAI AND F. QI, Some inequalities for $\left(s_{1}, m_{1}\right)-\left(s_{2}, m_{2}\right)$-convex functions on the co-ordinates, Glob. J. Math. Anal. 1 (2013), no. 1, 22-28.

[3] S.-P. BAI, S.-H. WANG, AND F. QI, Some Hermite-Hadamard type inequalities for $n$-time differentiable $(\alpha, m)$-convex functions, J. Inequal. Appl. 2012, 2012: 267, 11 pages, available online at http://dx.doi.org/10.1186/1029-242X-2012-267.

[4] M. E. ÖZdemir, M. TunÇ, AND M. GÜrBÜZ, Definitions of $h$-logaritmic, $h$-geometric and $h$ multi convex functions and some inequalities related to them, available online at http://arxiv.org/abs/1211.2750.

[5] Y. ShuAng, H.-P. YIN, AND F. QI, Hermite-Hadamard type integral inequalities for geometricarithmetically s-convex functions, Analysis (Munich) 33 (2013), no. 2, 197-208, available online at http://dx.doi.org/10.1524/anly.2013.1192.

[6] S. VARošAnec, On h-convexity, J. Math. Anal. Appl. 326 (2007), no. 1, 303-311, available online at http://dx.doi.org/10.1016/j.jmaa.2006.02.086.

[7] B.-Y. XI, R.-F. BAI, AND F. QI, Hermite-Hadamard type inequalities for the $m$ - and $(\alpha, m)$ geometrically convex functions, Aequationes Math. 184 (2012), no. 3, 261-269, available online at http://dx.doi.org/10.1007/s00010-011-0114-x.

[8] B.-Y. XI AND F. QI, Hermite-Hadamard type inequalities for functions whose derivatives are of convexities, Nonlinear Funct. Anal. Appl. 18 (2013), no. 2, 163-176.

[9] B.-Y. XI AND F. QI, Some Hermite-Hadamard type inequalities for differentiable convex functions and applications, Hacet. J. Math. Stat. 42 (2013), no. 3, 243-257.

[10] B.-Y. XI AND F. QI, Some inequalities of Hermite-Hadamard type for h-convex functions, Adv. Inequal. Appl. 2 (2013), no. 1, 1-15.

[11] B.-Y. XI, S.-H. WANG, AND F. QI, Properties and inequalities for the $h$ - and $(h, m)$-logarithmically convex functions, Creat. Math. Inform. (2013), no. 2, in press.

[12] B.-Y. XI, Y. WANG, AND F. QI, Some integral inequalities of Hermite-Hadamard type for extended $(s, m)$-convex functions, Transylv. J. Math. Mechanics 5 (2013), no. 1, 69-84.

[13] T.-Y.ZHANG, A.-P. JI, AND F. QI, Integral inequalities of Hermite-Hadamard type for harmonically quasi-convex functions, Proc. Jangjeon Math. Soc. 16 (2013), no. 3, 399-407.

[14] T.-Y. Zhang, A.-P. JI, AND F. QI, On integral inequalities of Hermite-Hadamard type for sgeometrically convex functions, Abstr. Appl. Anal. 2012 (2012), Article ID 560586, 14 pages, available online at http://dx.doi.org/10.1155/2012/560586. 
[15] T.-Y. Zhang, A.-P. Ji, AND F. QI, Some inequalities of Hermite-Hadamard type for GA-convex functions with applications to means, Matematiche (Catania) 68 (2013), no. 1, 229-239, available online at http://dx.doi.org/10.4418/2013.68.1.17. 